University of Nebraska - Lincoln DigitalCommons@University of Nebraska - Lincoln

2010

\title{
Pre-Mortem Cryopreservation: Recognizing a Patient's Right to Die in Order to Live
}

Ryan Sullivan

University of Nebraska College of Law, sullivan@unl.edu

Follow this and additional works at: http://digitalcommons.unl.edu/lawfacpub

Part of the Health Law and Policy Commons

Sullivan, Ryan, "Pre-Mortem Cryopreservation: Recognizing a Patient's Right to Die in Order to Live" (2010). College of Law, Faculty Publications. 191.

http://digitalcommons.unl.edu/lawfacpub/191

This Article is brought to you for free and open access by the Law, College of at DigitalCommons@University of Nebraska - Lincoln. It has been accepted for inclusion in College of Law, Faculty Publications by an authorized administrator of DigitalCommons@University of Nebraska - Lincoln. 


\title{
Pre-Mortem Cryopreservation: Recognizing a Patient's Right to Die in Order to Live
}

\author{
Ryan Sullivan*
}

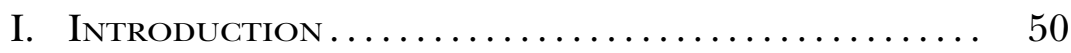

II. The Science of Cryonic Preservation ......... 53

A. History of Cryonics .................. 53

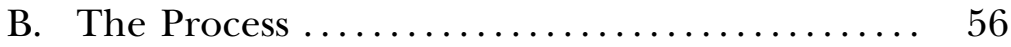

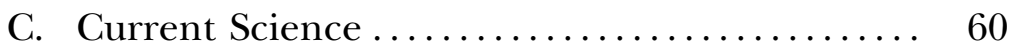

1. Cryobiology $\ldots \ldots \ldots \ldots \ldots \ldots \ldots \ldots \ldots \ldots, 61$

a. Successful Births with Once-Frozen Embryos...................... 62

b. If You Can Thaw a Frozen Dog . . . ... 63

c. Surgeries Performed During Suspended Animation...................... 64

d. Successful Revival After Three Hours of Clinical Death.................... 65

2. Advancements in Nanotechnology ....... 66

3. Obstacles to Overcome ................. 67

III. Relevant Law........................... 70

A. Laws Governing Cryonics................ 70

B. Right to Die and Assisted Suicide .......... 72

C. States' Interests are Not Compelling ......... 76

1. Interest in Preserving Life and Preventing Suicide ......................... 76

2. Interest in Maintaining Medical Ethical Standards ........................ 79

3. Interest in Protecting Vulnerable Persons and Preventing Abuse ............... 80

4. Are There Health Care Cost Savings to Consider? ........................... 81

IV. Conclusion .............................. 83

* J.D., May 2010, University of Nebraska; M.S., 2005, California University of Pennsylvania; B.S., 2002, Colorado State University. 


\section{Introduction}

" $[\mathrm{I}] \mathrm{n}$ this world nothing is certain but death and taxes." ${ }^{1}$ Is it possible that Ben Franklin was only half right? Advancements in cryobiology, the study of biological systems at a very low temperature, have led many to believe that immortality may be achievable through cryopreservation. The belief is that if a body is properly preserved, the patient can effectively "wait" for the scientific and medical advancements necessary to reanimate and cure the body of the fatal injury or disease. The primary objective in the preservation process is to preserve the brain. The brain contains neurological information that makes up the identity and memories of the person being preserved. If the brain is severely damaged, reanimation is not thought possible.

In the ideal case, the cryopreservation procedure begins immediately after the person is pronounced clinically dead, ensuring the brain is cooled and preserved before any damage can occur. This perfect scenario is not possible, however, for a cryonicist (i.e., an individual pursuing cryopreservation) suffering from a terminal brain disease, such as cancer. ${ }^{2}$ In this case, by the time the patient dies "naturally" from the cancer, his or her brain is already destroyed - there is nothing left to preserve. To maintain any chance of future reanimation, the patient must be preserved prior to the cancer consuming the brain - preservation must commence pre-mortem. This, of course, raises numerous thorny issues involving privacy, self-determination, morality, and assisted suicide.

Over the past 50 years, a trend towards a stronger constitutional right to privacy and self-determination has emerged - beginning with Griswold v. Connecticut ${ }^{3}$ in 1965, then Roe v. Wade $e^{4}$ in 1973. More recently, the Supreme Court has recognized a pa-

1 Letter from Benjamin Franklin to M. Leroy (1789), in BARTLETT's FAMiliaR Quotations 423 (Emily Morison Beck ed., Little Brown and Company 14th ed. 1968).

2 Other diseases causing irreparable damage to the brain include hydrocephalus, cerebral palsy, leukemia, Alzheimer's, Parkinson's, dementia, Creutzfeld-Jakob, encephalitis, multiple sclerosis, fibrodysplasia, and meningioma. This note often refers to brain cancer, but any of these or other progressive brain diseases would be equally relevant.

3381 U.S. 479 (1965). In this historic case, the United States Supreme Court held that the Constitution protected a citizen's right to privacy. The case involved a Connecticut law that prohibited the use of contraceptives. The Supreme Court invalidated the law on the grounds that it violated the right to marital privacy.

4410 U.S. 113 (1973). The Supreme Court held that a woman's right to have an 
tient's right to refuse medical treatment, ${ }^{5}$ and some states have found a right to assistance in committing suicide. ${ }^{6}$ When such privacy rights are found, courts then balance these rights against the competing state interests in preserving life, preventing suicide, and maintaining medical integrity. For the cryonicist patient's right to pre-mortem preservation to prevail, the court must find legitimacy in the theory of cryonics.

Today, most view cryonics as mere science fiction, dramatized in feature films such as Vanilla Sky ${ }^{7}$ and Sleeper ${ }^{8}$, and in the popular animated series Futurama. ${ }^{9}$ Cryonics is no more immune to criticism than any other "out there" theory that challenges mainstream thought and science. Just over a century ago, human air travel was viewed as science fiction. ${ }^{10}$ In fact, in 1908, Orville Wright himself wrote in a letter, "No flying machine will ever fly from New York to Paris. That seems to me to be impossible." ${ }^{11}$ Less than twenty years later Charles Lindbergh did just that, flying over 3,500 miles non-stop from New York to Paris in 1927. ${ }^{12}$ Just 50 years ago, ${ }^{13}$ the thought of space travel existed only in the imaginative tales of science fiction authors like Jules

abortion was within the right to privacy protected by the Due Process Clause of the Fourteenth Amendment.

5 See Cruzan v. Mo. Dep't of Health, 497 U.S. 261 (1990).

6 See Washington Death with Dignity Act, WAsh. Rev. Code $\$ \S 70.245 .010-.904$ (2010); Baxter v. State, No. ADV-2007-787, 2008 WL 6627324 (Mont. Dist. Ct. Dec. 5, 2008), rev'd on other grounds, 224 P.3d 1211 (Mont. 2009).

7 (Paramount Pictures 2001). In this film the main character, played by Tom Cruise, is cryogenically preserved after a car accident and later given the option to be revived, or continue living in his subconscious.

8 (Rollins-Joffe Productions 1973). A Woody Allen film depicting a man frozen and revived in the future by anti-government radicals in order to assist them in their attempts to overthrow an oppressive government.

9 (20th Century Fox Television 1999). Futurama follows the comic exploits of Phillip J. Fry, a pizza delivery boy, who was accidentally cryogenically frozen in 1999, and is revived in the year 3000 .

10 See The Langley Aeroplane, N.Y. Times, Dec. 10, 1903, at 8; see also Michael Marshall, 10 Impossibilities Conquered by Science, NewScientist (Apr. 3, 2008, 3:30 PM), http:/ /www.newscientist.com/article/dn13556-10-impossibilities-conquered-by-science.html? full=true ("The number of scientists and engineers who confidently stated that heavierthan-air flight was impossible in the run-up to the Wright brothers' flight is too large to count. Lord Kelvin is probably the best-known. In 1895 he stated that 'heavier-than-air flying machines are impossible', only to be proved definitively wrong just eight years later.").

11 See Mitchell Symons, M., How To Avoid A Wombat's Bum . . . And Other Fascinating Facts 84-85 (2006).

12 See Tom D. Crouch et Al., Charles A. Lindbergh: An American Life (1977).

13 In 1961, Soviet cosmonaut Yuri Gagarin became the first human to travel into outer-space. Yury Alekseyevich Gagarin, EnCYClopædia BRITANnICA, http://www.britan 
Verne. ${ }^{14}$ Human space travel was thought impossible because it was thought that the human body could not survive the burst of acceleration needed to escape Earth's gravitational pull. We all know how that turned out.

What about resurrecting the dead? Science fiction too? For centuries, the idea of resurrecting the dead was considered an absurd fantasy - even supernatural. ${ }^{15}$ But in the last 50 years, with the advent of $\mathrm{CPR}^{16}$ and the use of Automated External Defibrillators (AEDs), ${ }^{17}$ it has become not only a reality, but also a regularity. Presently, humans are resuscitated from clinical death on a regular basis, and go on to live full, healthy lives.

Today's science fiction is tomorrow's science reality. Cryonics is clearly in its early stages of growth, but recent developments indicate that it might be realized in this century. Scientists are already cryogenically preserving and reviving mammal organs ${ }^{18}$ and embryos ${ }^{19}$. Cryonicists wholeheartedly believe these small steps are proof that it is possible - that future science will hold the capability of reanimating whole human beings.

The first aircraft flew barely a hundred feet; now jets can circle the globe. Humans have been resuscitated after as long as

nica.com/EBchecked/topic/223437/Yury-Alekseyevich-Gagarin (last visited Jan. 5, 2011).

14 Jules Verne, From the Earth to the Moon (Lowell Bair trans., Bantam Books 1993) (1865). Verne writes a fictional tale of a group of obsessive American Civil War veterans who conceive the idea of creating an enormous cannon in order to shoot a "space-bullet" to the Moon.

15 However, resurrecting the dead has been present in religion. For instances in the Old Testament, see 1 Kings 17:22; 2 Kings 4:32-:35; 2 Kings 13:21. For instances in the New Testament, see Matthew 9:23-:25; Mark 5:39-:42; Matthew 27:52; Luke 7:15; John 11:38-:44; Acts 9:40; Acts 20:9-:12.

16 See History of CPR, American Heart Association, http://www.americanheart. org/presenter.jhtml?identifier=3012990 (last updated July 15, 2009). In 1960, "[c] ardiopulmonary resuscitation (CPR) was developed. The American Heart Association started a program to acquaint physicians with close-chest cardiac resuscitation and became the forerunner of CPR training for the general public." Id.

17 See Joseph J Bocka, Automatic External Defibrillation, EMEdicine, http:// emedicine.medscape.com/article/780533-overview (last updated Apr. 9, 2009). "In the 1990s, AED [(automated external defibrillator)] use by lay personnel was approved by the FDA and Good Samaritan legislation soon followed. AED training was included in the American Red Cross basic CPR course beginning in March of 1999. In November 2002, the Phillips HeartStart AED was approved for home use with a prescription. New York State became the first state to mandate AEDs in schools in May 2003. The Federal Aviation Administration (FAA) mandated in April 2004 that all large passenger-carrying US airlines carry and have personnel trained in the use of AEDs." Id.

18 See infra note 40.

19 See infra note 42. 
three hours of clinical death. ${ }^{20}$ If it can be done after three hours, why not after 300 years? It is just a matter of time. Having considered both the national trend towards increased constitutional privacy protection and the substantial advancements in cryobiology and other supporting sciences, this note argues that courts should recognize a terminally-ill brain cancer patient's constitutional right to receive assistance in achieving premortem cryopreservation.

Part II offers a brief overview of cryonics, including its history, the process, and the prospect of future successful animation. Part III addresses relevant federal and state laws which provide guidance as to the legality of pre-mortem cryopreservation. Finally, Part IV analyzes the various state interests at issue, and concludes that these interests are not compelling in the particular case involving the terminally ill patient seeking future life through pre-mortem cryopreservation.

\section{The Science of Cryonic Preservation}

\section{A. History of Cryonics}

It is assumed that the origins of cryonic preservation and reanimation lie in the imaginative minds of science fiction authors. In actuality, cryonics has its roots in the writings of some of our most famous and prolific historical characters and scientists. In 1773, in a letter to Jacques Dubourg discussing Dubourg's proposed experiments for resuscitating people killed by lightning, Benjamin Franklin wrote,

I wish it were possible . . . to invent a method of embalming drowned persons, in such a manner that they might be recalled to life at any period, however distant; for having a very ardent desire to see and observe the state of America an hundred years hence, I should prefer to an ordinary death . . . ! But . . . in all probability, we live in a century too little advanced, and too near the infancy of science, to see such an art brought in our time to its perfection . . . ${ }^{21}$

Fast forward nearly 200 years, and you will stumble across

20 See infra Part II.C.1.d.

21 Benjamin Franklin, Mr. Franklin: A Selection from His Personal letters 28-29 (Leonard W. Labaree \& Whitfield J. Bell, Jr. eds., 1956). 
The Prospect of Immortality, ${ }^{22}$ a ground-breaking book written by physics professor Dr. Robert Ettinger. In his book, Dr. Ettinger describes the process of freezing a human as a means of accessing future medical technology. ${ }^{23}$ His hypothesis rested upon two theories. First, some conditions that are terminal today may be curable in the future. ${ }^{24}$ Second, the early stages of clinical death, e.g., the cessation of a heartbeat, may be reversible in the future. ${ }^{25}$ Combining these ideas, Ettinger believed that freezing the body of a person recently deceased would create an alternative means to save that person's life, and to avoid death altogether. ${ }^{26}$ Essentially, the freezing process pauses life just before biological death, ${ }^{27}$ creating an opportunity to await future medical advancements. Ettinger's book was published by in 1962 and, because of its publicity, sparked the modern era of cryonics. ${ }^{28}$

Two years earlier, but with less fanfare, a similar book was published by Ev Cooper (writing as Nathan Duhring) titled, Immortality: Physically, Scientifically, Now ${ }^{29}$ Like Ettinger, Cooper described how cryogenically freezing the human body creates "a possibility for eventually defeating death." ${ }^{30}$ Cooper went on to

22 Robert C. W. Ettinger, The Prospect of Immortality (1964).

23 Id. at 1.

$24 \mathrm{Id}$.

$25 I d$. at 3.

26 Id. Ettinger believes that "[b]y preserving our bodies in as nearly life-like a condition as possible, it is clear that you and I, right now, have a chance to avoid permanent death." Id. at 2. He suggests that humans should take advantage of the developments in cryobiology and have "their bodies frozen instead of buried or cremated." Eschatology: Freeze-Wait-Reanimate, Time, Sept. 30, 1966, at 99, available at http://www.time.com/ time/printout/0,8816,836463,00.html.

27 Biological death is also known as "brain death." George P. Smith, II, Pathways to Immortality in the New Millennium: Human Responsibility, Theological Direction, or Legal Mandate, 15 St. Louis U. Pub. L. Rev. 447, 461-62 (1996). "There are basically two types of death: clinical and biological. Clinical death precedes biological death and normally occurs when one's heart and respiratory systems stop. . . . However, from a biological point of view, death occurs gradually. Thus, even after a recognition of clinical death, certain biological activities occur." Id. at 461. Even "at low body temperature clinical death is not synonymous with biological death." Ulrich Althaus et al., Management of Profound Accidental Hypothermia with Cardiorespiratory Arrest, 195 ANNALS Surgery 492 (1982).

28 See Nick Bostrom, A History of Transhumanist Thought, 14 J. Evolution \& Tech. $1,10(2005)$.

29 Nathan Duhring, Immortality: Physically, Scientifically, Now, Depressed MetaboLISM, http:/ / depressedmetabolism.com/pdfs/cooper_immortality.pdf (last visited November 11, 2010) (offering an online version of the 1962 independently self-published book).

30 Id. Cooper identified several indicia of the possibility of immortality, including 
found the Life Extension Society in 1963, the first cryonics organization in the world. ${ }^{31}$ In 1965, Karl Werner coined the term "cryonics" from the Greek word, "cryo," meaning cold, in conjunction with the founding of the Cryonics Society of New York. $^{32}$ In 1966, the Cryonics Society of Michigan and the Cryonics Society of California were founded. ${ }^{33}$

The first person to be cryogenically preserved with the goal of future reanimation was Dr. James Bedford, a 73-year-old psychology professor. ${ }^{34}$ Bedford was frozen in 1967 by the Cryonics Society of California, now known as Alcor Life Extension Foundation, and remains frozen today. ${ }^{35}$ Since then approximately 200 human bodies have been cryogenically preserved by three different U.S.-based non-profit groups offering preservation services $^{36}$ : Alcor, ${ }^{37}$ the Cryonics Institute, ${ }^{38}$ and the American Cryonics Society. ${ }^{39}$

Since Bedford in 1967, many advancements in cryogenic technology and medicine have been observed. In fact, the process of cryogenic preservation is used today in mainstream

regeneration, transplantation, hibernation, and low-temperature preservation of small animals. Id. Cooper goes on to state that "[p]resent scientific research seems to indicate [that low-temperature preservation] would be the best way, in general, to store the body until techniques of resuscitation and the postponing of death are perfected." Id.

31 See Mike Perry, For the Record: Unity and Disunity in Cryonics, 13 Cryonics 4, 5 (1992), available at http://www.alcor.org/cryonics/cryonics9208.txt; see also Ev Cooper, 1983 CRYONICS 7, available at http://www.alcor.org/cryonics/cryonics8303.txt.

32 Saul Kent, The First Cryonicist, 1983 CRYONICS 9, 10, available at http:/ /www.alcor. org/cryonics/cryonics8303.txt; see also Daniel R. Spector, Legal Implications of Cryonics, 18 Clev.-Marshall L. Rev. 341, 341 (1969).

33 Kent, supra note 32 , at 12.

34 Mike Perry, For the Record: The First Suspension, 12 Cryonics 11, 13 (1991).

35 Complete List of Alcor Cryopreservations, Alcor, http://www.alcor.org/cases.html (last visited Nov. 28, 2010); see also Thomas Robbins and Susan J. Palmer, Millennium, MESSIAHS, AND MAYHEM: CONTEMPORARY APOCALYPTIC MOVEMENTS 145 (1997).

36 Comparing Procedures and Policies, CRYonics Institute, http://www.cryonics.org/ comparisons.html\#Existing (last visited Nov. 20, 2010).

37 Alcor Membership Statistics, Alcor, http://www.alcor.org/AboutAlcor/member shipstats.html (last visited Nov. 20, 2010) ("As of October 31, 2010, Alcor has 925 members and 101 patients.").

38 Cryonics Institute (CI) Member Statistics Details, Cryonics Institute, http://cryon ics.org/statistics_details.html (last visited Nov. 20, 2010) (stating that as of November 1, 2010, the Cryonics Institute had 101 patients).

39 See Key Features of the American Cryonics Society Suspension Program, American CrYONICS Society, http://www.americancryonics.org/acsadvan.htm (last visited Nov. 20, 2010) (explaining that patients of the American Cryonics Society are suspended through the Cryonics Institute); see also Comparing Procedures and Policies, supra note 36 (explaining that the patient count of Cryonics Institute includes those patients of the American Cryonics Society). 
medicine for the purposes of organ, ${ }^{40}$ blood, ${ }^{41}$ and embryo ${ }^{42}$ preservation. Further, the techniques used for human body cryopreservation have evolved with the advent of vitrification and other scientific breakthroughs, which have eliminated many of the obstacles once preventing the realization of cryonic preservation and reanimation. ${ }^{43}$

\section{B. The Process}

Although the process of human preservation has improved substantially over the years, the basic concept remains the same. ${ }^{44}$ Typically, the procedure begins immediately upon the onset of clinical death. ${ }^{45}$ In cases where imminent death is known in advance, a suspension team is often placed on location at the hospital in order to expedite the process and ensure immediate cooling. ${ }^{46}$ This is often referred to as "standby" service. ${ }^{47}$ To ensure proper steps are taken by medical staff in cases where death is unexpected, members of their respective cryonic

40 See, e.g., Andrew A. Skolnick, Tissue Bank Expands Facilities, Efforts, 266 JAMA 1329, 1330 (1991) (explaining how human heart valves are removed and "refrigerated" for later transplantation).

41 See, e.g., Charles E. Huggins, Frozen Blood, 160 Annals Surgery 643 (1964). Gary K. Shen \& William Rappaport, Control of Nonhepatic Intra-abdominal Hemorrhage with Temporary Packing, 174 Surgery, Gynecology \& Obstetrics 411 (1992) (explaining the various medical uses of previously frozen blood products).

42 Kimberly E. Diamond, Cryogenics, Frozen Embryos and the Need for New Means of Regulation: Why the U.S. is Frozen in Its Current Approach, 11 N.Y. INT'L L. REv. 77, 78 (1998) ("Infertility clinics in the United States and elsewhere are drawing upon advances in cryogenics to ... store these embryos at the in vitro fertilization (IVF) clinic for future implantation.").

43 Jerry Lemler et al., The Arrest of Biological Time as a Bridge to Engineered Negligible Senescence, 1019 Annals N.Y. ACAD. ScI. 559, 560 (2004), available at http://www.alcor. org/Library/pdfs/Lemler-Annals.pdf.

44 The concept visualized by both Ettinger and Cooper was low-temperature preservation. However, cryonics patients are no longer frozen. Instead, they are vitrified, a process of low temperature preservation that suspends molecular activity without freezing. See infra Part II.C.1.a.

45 See supra note 27.

46 Outline of CI Cryopreservation Procedures for Human Patients, Cryonics Institute, http://www.cryonics.org/phases.html (last visited Nov. 20, 2010) [hereinafter Outline of CI] ("If possible, CI Members should arrange to have a team of cryonicists standing by their bedside when they are in a terminal condition. Such a team can initiate rapid cooldown with a portable ice bath and [an Active Compression DeCompression HeartLung Machine ("ACDC")] Thumper.").

47 Frequently Asked Questions: Page 6 - Membership Questions, Alcor, http://www. alcor.org/FAQs/faq06.html (last visited Nov. 20, 2010) (answering the question "[w] hat is a "standby", and do I need one?"). Standby services are sometimes an additional expense not included in the cryopreservation fee. See Cryonic Suspension Agreement, Cryonics Institute, http://www.cryonics.org/documents/CS_Agreement.html 
societies often wear identification bracelets ${ }^{48}$ or carry a cryonics card with specific instructions. ${ }^{49}$ The key to a successful cryogenic suspension is immediacy - it is crucial that the patient be suspended before any damage to the brain occurs. ${ }^{50}$

Three initial steps are performed with the specific intent to protect the brain. First, the body of the patient must be cooled immediately after death. ${ }^{51}$ Science and history have proven that under normal conditions a human cannot be resuscitated after prolonged clinical death, mainly due to the lack of oxygen to the brain. ${ }^{52}$ However, cold-water drowning victims have been known to have been resuscitated after an hour or more. ${ }^{53}$ Thus, cooling the body early increases the likelihood of future revival of brain functions.

Next, the patient is injected with medications ${ }^{54}$ which are

(last visited Nov. 20, 2010) (cryopreservation agreement utilized by the Cryonics Institute).

48 Alcor provides every member with an identification bracelet and necklace. These stainless-steel items are engraved with the member's identification number and emergency instructions. Frequently Asked Questions: Page 6 - Membership Questions, supra note 47 (answering the question "[h] ow will people know I am an Alcor member in an emergency?").

49 Emergency Jewelry and Wallet Cards, Cryonics Institute, http://www.cryonics. org/jewelry.html (last visited Nov. 20, 2010); see also Email from Ben Best, President, Cryonics Institute, to author (Nov. 21, 2009, 08:34 AM) (on file with author).

50 See EtTinger, supra note 22, at 32 ("[I]f the oxygen supply is cut off, the brain ordinarily seems to suffer damage within three to eight minutes."). Cryonicists believe that as long as the brain is preserved, the future will hold the technology to replicate or regenerate the rest of the body. Ben Best, Emergency Preparedness for Local Cryonics Group, BENBEST.cOM, http://www.benbest.com/cryonics/localres.html ("The damage that can occur to the brain of a cryonics patient immediately after death is potentially far greater and more irreversible than any damage incurred in a cryopreservation protocol. Nanotechnology may one day be capable of repairing freezing damage, but it is unlikely to be able to repair degraded or dissolved brain tissue.").

51 Outline of CI, supra note 46; see also Benjamin P. Best, Scientific Justification of Cryonics Practice, 11 Rejuvenation Res. 493, 493-94 (2008) [hereinafter Scientific Justification] ("Following legal death, a cryonics team can begin preservation procedures immediately. ... [T] he subject is administered protective medicines and is rapidly cooled to a temperature between $10^{\circ} \mathrm{C}$ and $\left.0^{\circ} \mathrm{C} . "\right)$.

52 Harold L. Hirsh, Brain Death, 1975 Med. Trial Tech. Q. 377, 378-79.

53 See Richard S. K. Young et al., Neurological Outcome in Cold Water Drowning, 244 JAMA 1233 (1980); see also Thomas G Martin, Neardrowning and Cold Water Immersion, 13 Annals Emergency Med. 263, 270 (1984).

54 Scientific Justification, supra note 51, at 499 ("Once cardiac arrest has occurred and death has been pronounced, a cryonics subject can be given medications to maintain sedation, reduce cerebral metabolism, prevent/reverse blood clotting, increase blood pressure, stabilize $\mathrm{pH}$ against acidosis, and protect against ischemia/reperfusion injury."). 
circulated through the body by using chest compressions. ${ }^{55}$ In order to preserve the brain, it must be cooled and medicated through the body's circulatory system. ${ }^{56}$ Once clinical death has been pronounced, the anticoagulant heparin is injected to keep the circulatory system free of blood clots. ${ }^{57}$

The third step in maintaining viability of the brain is to provide metabolic support by supplying the brain cells with oxygen and glucose. ${ }^{58}$ Oxygen can be provided via intubation, ${ }^{59}$ and glucose and other medications can be provided intravenously ${ }^{60}$ Metabolic sustainment may also be accomplished through a process called Cardiopulmonary Support. ${ }^{61}$ Essentially, these procedures keep much of the body "alive" until long-term preservation temperatures can be achieved. ${ }^{62}$

Once the preliminary steps have been performed, the cryonics specialists must execute the process of "vitrification." ${ }^{3}$ The patient cannot be supercooled immediately because the water inside his or her cells would freeze. Scientists have discovered that when the cells of a mammal are frozen, water leaks out and forms ice crystals, which crush the fragile cell membranes and create irreparable damage to the organs - most importantly,

55 Charles Platt, General Introduction to Procedures for Alcor Transport Technicians, ALCOR, 8, http://www.alcor.org/Library/pdfs/intro.pdf (last updated Feb. 2004).

$56 \mathrm{Id}$.

57 Both Alcor and the Cryonics Institute use heparin as an anti-clotting agent. Platt, supra note 55; Ben Best, Quantifying Ischemic Damage for Cryonics Rescue, BenBest.COM, http://www.benbest.com/cryonics/IR_Damage.html ("Heparin has been used by the Cryonics Institute to prevent blood clotting in cryonics patients prior to shipment to CI by a funeral director.").

58 Platt, supra note 55.

59 Id. Intubation is a medical procedure whereby a medical staff member inserts a tube through the mouth down into the trachea and supplies the lungs with fresh oxygen. Richard Sloane, The Sloane-Dorland Annotated Medical-Legal Dictionary 386 (1987).

60 Platt, supra note 55.

61 Scientific Justification, supra note 51, at 499-500 ("Cryonics procedures involve restoring blood circulation and respiration as soon as possible to keep tissues alive. In cryonics, this is called cardiopulmonary support (CPS) rather than cardiopulmonary resuscitation (CPR) because resuscitation after death has been pronounced is not desired (a do not resuscitate [DNR] condition).”).

$62 I d$.

63 Vitrification, in the medical realm, is defined as " $[\mathrm{a}] \mathrm{n}$ experimental procedure for preserving human organs in which chemicals are added prior to cooling to prevent crystallization of water within and outside the cells, so that with coolings the molecules essentially become fixed in place." McGraw-Hill Dictionary of Scientific and TechNICAL TERMs 2266 (6th ed. 2003). In cryonics, the vitrification process is also called "washout and perfusion." See Outline of CI, supra note 46. 
to the brain. ${ }^{64}$ To prevent this occurrence, the blood is removed and a glycerol based substance ${ }^{65}$ is pumped through the body, ${ }^{66}$ effectively replacing the water in the cells with what cryonicists call a "cryoprotectant" - an antifreeze for the human body. ${ }^{67}$ Once a significant amount of water in the body has been replaced with cryoprotectant, the body is cooled to approximately $120^{\circ}$ Celsius, completing the vitrification process. ${ }^{68}$

The final step in the cryopreservation process is to insert the body into a large metal tank filled with liquid nitrogen ${ }^{69}$ where the body is cooled to its long-term storage temperature of approximately $-196^{\circ}$ Celsius. ${ }^{70}$ Although the liquid nitrogen will keep the patient cooled indefinitely, it must be replenished regularly due to its constant slow boil-off. ${ }^{71}$ Patients are typically

64 Platt, supra note 55, at 9-10; see also Email from Brian O’Neill, Member, Cryonics Institute, to Ryan Sullivan, Student, University of Nebraska College of Law (Nov. 14, 2009, 12:10 CST) (on file with author) ("What I believe I am trying to preserve through cryonics is identity - 'me' as I exist to myself and to others. Most people believe that people retain their identity even when they lose appendages, or a kidney, or even when they have a heart transplant. However, I believe most people would agree that damage to the brain would cause damage to one's identity, and because this particular organ is so incredibly complex, it is the single organ that should be preserved as 'pristinely' as possible in order to have the best chance of retaining identity through cryonics. . . So the brain remains as the organ most important to 'long life." ).

65 The Cryonics Institute uses a glycerol-based substance called CI-VM-1, a vitrification mixture developed by Dr. Yuri Pichugin, the Institute's in-house cryobiologist. CIVM-1 Cryoprotectant and CI-Carrier Solution Used for Vitrification, CRYONICS INSTITUTE, http:/ /www.cryonics.org/research/CI-VM-1.html (last visited Nov. 20, 2010) [hereinafter CI-VM-1 Cryoprotectant]. Alcor utilizes a substance called Supercool X-1000 Ice Blocker, produced by 21st Century Medicine, which incorporates "ice blockers" that prevent ice formation during vitrification. Alcor at Work Photo Gallery: Facility Equipment, Alcor, http://www.alcor.org/AtWork/p2facility.html (last visited Nov. 20, 2010).

66 The act of pumping the cryoprotectant through the body is called "perfusion." Smith, supra note 27, at 460-61; see also Ben Best, Perfusion Eं Diffusion in Cryonics Protocol, BenBest.com, http://www.benbest.com/cryonics/protocol.html (last visited Nov. 20, 2010).

67 Outline of CI, supra note 46. The cryoprotectant mixture is stored at refrigerator temperature. Id. Thus, the act of perfusion itself assists in the cooling of the body.

$68 \mathrm{Id}$. (After washout and perfusion, "the patient is placed in a sleeping bag, tagged, and cooled down further, taking several hours to cool down to $-120^{\circ} \mathrm{C}$. . . ."); see also Platt, supra note 55, at 10-11.

69 Outline of CI, supra note 46 ("At the end of cooling, the patient is fully is [sic] transferred to a cryostat (long term storage unit), which is done quickly, the sleeping bag saturated with nitrogen, with no appreciable warm-up during transfer.")

70 Cryonics: A Basic Introduction (Continued), Cryonics Institute, http://www.cryon ics.org/prod2.html (last visited Nov. 20, 2010).

71 See Ben Best, Cryostats for Cryogenic Storage, Cryonics Institute, http://www. cryonics.org/cryostats.html (last visited Nov. 20, 2010) ("The cylinders [storage units] are filled weekly, whereas the rectangular [storage] units are filled twice weekly. . . . The level of liquid nitrogen in the most efficient cylinders drops only a bit more than 2 inches in a week."). 
inserted in the container vertically head-first as added protection against a catastrophic boil-off of liquid nitrogen. ${ }^{72}$ This way, the brain would remain preserved even if portions of the body were accidentally allowed to thaw. ${ }^{73}$

The cost of human cryogenic preservation varies depending on the facility ${ }^{74}$ but can cost upwards of $\$ 174,000$, including standby fees and ongoing preservation expenses. ${ }^{75}$ Many cryonicists move near their chosen facility to ensure immediate preservation and to reduce costs. ${ }^{76}$ There are several ways to pay for the procedure. Some prepay, but many cryonicists purchase life insurance policies with the designated cryonics institution listed as the beneficiary. ${ }^{77}$ It is suggested that the patient purchase additional life insurance, if feasible, in order to counter any inflation. ${ }^{78}$ Of course, if the patient is terminally ill, this will not be a factor.

\section{Current Science}

The science of cryonics has advanced substantially over the 40-odd years following the birth of its popularity in the mid1960s. The once absurd theory of future reanimation has not

72 See Id.

73 Id. ("Should a disaster occur - which has not happened since we began service in 1976 - the feet would be the first to suffer exposure and the head the last.").

74 Comparing Procedures and Policies, supra note 36.

75 Preservation through the Cryonics Institute costs $\$ 28,000$ for perfusion and storage, plus $\$ 88,000$ for standby service (optional), and a $\$ 1,250$ lifetime membership fee. Membership Application, CRYONICS InSTITUTE, http://www.cryonics.org/membership.html (last visited Nov. 20, 2010). Alcor charges $\$ 150,000$ for whole body cryopreservation including standby services, $\$ 20,000$ for a lifetime membership, and $\$ 4,000$ in additional standby fund charges. Alcor Cryopreservation Agreement - Schedule A: Required Costs and and Cryopreservation Fund Minimums, Alcor, http://www.alcor.org/BecomeMember/ scheduleA.html [hereinafter Fund Minimums].

76 Telephone Interview with Brian O'Neill, Member, Cryonics Institute (Nov. 21, 2009). In fact, Alcor has a policy that "[a]ny Member not already residing in the greater Phoenix, Arizona area who is diagnosed as being terminally ill with a prognosis of ninety (90) days or less and who relocates to a residence or terminal care facility in the greater Phoenix, Arizona area will be entitled to a onetime $\$ 5,000.00$ expense relocation reimbursement ...." Fund Minimums, supra note 75.

77 Becoming a Member: The FAQ CRYONICS Institute, http://www.cryonics.org/ become.html (last visited Nov. 20, 2010); Funding Methods for Cryopreservation at Alcor, ALCOR, http://www.alcor.org/BecomeMember/sdfunding.htm (last visited Nov. 20, 2010)

78 Becoming a Member: The FAQ supra note 77; Frequently Asked Questions: Page 6 Membership Questions, supra note 47 ("Alcor strongly recommends that funding above minimum amounts be obtained if possible to allow for inflation and future technical advances."). 
only become a possibility, but recent scientific developments have led some to believe that it is probable. In fact, at least one scientist believes we could see the first human reanimation by the year 2040. ${ }^{79}$ In recent decades, developments in the areas of cryobiology and nanotechnology have generated an abundant supply of data supporting the legitimacy of cryonics.

\section{Cryobiology}

There is often confusion between the terms cryonics, cryogenics, and cryobiology. Cryonics is the practice of "deep-freezing the bodies of those who have died of an incurable disease, in the hope that some cure for it will be discovered in the future." Cryogenics is a branch of physics, defined as the "technology that deals with the production of very low temperatures and their effects." ${ }^{1}$ Cryobiology, on the other hand, is a branch of biology that studies the effects of low temperatures on biological systems. ${ }^{82}$ Cryobiology was originally developed to preserve and store organs for transplants, ${ }^{83}$ but is now also used in the process of lyophilization, ${ }^{84}$ cryosurgery, ${ }^{85}$ supercooling, ${ }^{86}$ and the cryopreservation of cells, tissues, gametes, and embryos of animal and human origin for medical purposes of long-term storage. ${ }^{87}$

79 Brian Shock, A Few Questions and Answers with Robert Freitas, the Author of Nanomedicine, 20 CRYONICS 23, 24 (1999) ("Thus [Robert Freitas] would not be surprised if the first cryonics revival was attempted by 2040-2050.").

80 The New Shorter Oxford English Dictionary 563 (Lesley Brown ed., 1993). The term cryonics is conceptualized primarily within the sphere of burial; the distinction being that the objective of cryonics is not disposal, but preservation. W.T. Gordon, Miscellany, The Vocabulary of Cryonics, 50 Ам. SPEech 132, 133 (1975).

81 The New Shorter Oxford English Dictionary, supra note 80, at 563.

82 Id.; see also, Suspending Life in a Deep Freeze, Business Week, June 16, 1962, at 72 ("Essentially, cryobiology is the marriage of two separate sciences: cryogenics, or extreme low-temperature physics, and biology.").

83 Stacey Sutton, The Real Sexual Revolution: Posthumously Conceived Children, 73 ST. John's L. REv. 857, 869 n.72 (1999).

84 Lyophilization is freeze-drying or, more technically explained, it is " $\mathrm{t}]$ he removal of water under vacuum from a frozen sample; a relatively gentle process for the removal of water in which the water sublimes from the solid to the gaseous state." J. Stenesh, Dictionary of Biochemistry and Molecular Biology 282 (2d ed. 1989).

85 Cryosurgery (or cryotherapy) is a technique utilized by physicians whereby extreme cold is used to remove or destroy diseased tissue. 3 THE New Encyclopæoda BRITANNICA 767 (15th ed. 1992).

86 Supercooling is the process of lowering the temperature of a liquid or a gas below its freezing point, without it becoming a solid. MCGraw-Hill Dictionary of SCIentific And Technical Terms 2069 (6th ed. 2003).

87 See infra Part II.A. See generally Cryobiology, WikipediA, http://en.wikipedia.org/ wiki/Cryobiology (last visited Jan. 5, 2011). 
It is upon this science that the theory of cryonics is founded. Although modern cryobiology has yet to demonstrate the viability of human reanimation, successful reanimation of cryopreserved embryos and various small organisms provides hope that human reanimation technology will soon follow. Further, documented cases of humans being resuscitated after prolonged periods of clinical death give added support to the probability that future science will possess the ability to reanimate, repair, and cure cryogenically preserved humans.

\section{a. Successful Births with Once-Frozen Embryos}

Over 20 years ago, practitioners began successfully freezing human embryos to be stored for future implantation. ${ }^{88}$ In 1983, the first babies (twins) were born from a previously frozen embryo. ${ }^{89}$ Since then, the practice of cryogenically preserving human embryos has become common place in the practice of human fertility treatments. ${ }^{90}$ In fact, a study conducted from 1995 to 2006 revealed that babies born from frozen embryos that were thawed and implanted had a higher birth weight, and had no increased risk of abnormalities when compared to babies born from fresh implanted embryos and natural births. ${ }^{91}$

It was during experiments involving embryo preservation that the process of biological vitrification was developed. ${ }^{92}$ In reality, embryos are not frozen, they are vitrified ${ }^{93}$ or "cryogeni-

88 See Bloodlines: Timeline, PBS, http://www.pbs.org/bloodlines/timeline/text timeline.html (last visited Nov. 21, 2010) (providing a timeline of discoveries and advances in reproductive science including the first baby born from a frozen embryo in 1983).

89 Gerard H. Zeilmaker et al., Two Pregnancies Following Transfer of Intact FrozenThawed Embryos, 42 FertiLity \& STERILITy 293, 295 (1984).

90 Aniruddha Bagchi et al., Cryopreservation and Vitrification: Recent Advances in Fertility Preservation Technologies, 5 Expert Rev. Med. Devices 359, 359 (2008) ("Over the last half the 20th Century, reproductive medicine has become a critically important branch of modern medical science. Fertility preservation is a vital branch of reproductive medicine and involves the preservation of gametes (sperm and oocytes), embryos, and reproductive tissues (ovarian and testicular tissues) for use in artificial reproduction. ... The most common fertility preservation technique is cryopreservation, which involves freezing cells and tissues at cryogenic temperatures.”).

91 Anja Pinborg et al., Infant Outcome of 957 Singletons Born After Frozen Embryo Replacement: The Danish National Cohort Study 1995-2006, 94 Fertility \& Sterility 1320 (2010).

92 See Ed Stehlik et al., Vitrification Demonstrates Significant Improvement Versus Slow Freezing of Human Blastocysts, 11 Reprod. BioMedicine Online 53, 53-54 (2005).

93 Vitrification is the transformation of a substance into a glass-like material. MCGraw-Hill Dictionary of Scientific and Technical Terms 2266 (6th ed. 2003). 
cally suspended." As noted above, vitrification involves the replacement of water within the cells with a cryoprotectant that chills the embryo to a temperature just below $-120^{\circ}$ Celsius while preventing the formation of ice crystals. ${ }^{94}$

The vitrification process has now become standard procedure at all cryonics facilities. ${ }^{95}$ When performed correctly, the process removes approximately $60 \%$ of the water inside the cells and prevents actual freezing during deep cooling. ${ }^{96}$ Rather, instead of freezing, ${ }^{97}$ the molecules are gradually slowed to a point where all chemistry ceases at the "glass transition temperature (approximately $-124^{\circ} \mathrm{C}$ ). ${ }^{\prime 98}$ Vitrification has proven to be a remarkable advancement towards the realization of successful cryopreservation. While there are no records of reanimation of vitrified mammals to date, ${ }^{99}$ scientists have successfully suspended and recovered vitrified blood vessels ${ }^{100}$ and whole kidneys of rabbits. ${ }^{101}$

\section{b. If You Can Thaw a Frozen Dog. . .}

In 1987, Berkley scientists successfully performed a cryo-

94 See supra Part II.B.

95 See, e.g., Cryonic Myths, Alcor, http://www.alcor.org/cryomyths.html (last visited Nov. 21, 2010) ("The current technology favored by Alcor is vitrification."); CI-VM-1 Cryoprotectant, supra note 65 ("The Cryonics Institute (CI) has been using a mixture for vitrification of the brains of cryopreserved pets and humans since August 2004 . . ..").

96 Cryonics Myths, supra note 95. But see Robert Ettinger, Vitrification Facts and Prospects, Cryonics Institute (Dec. 29, 2000) http://www.cryonics.org/Dec_00_3.html (“At present, to our knowledge, there does not exist any proven method of vitrifying a human brain (or any mammalian brain) without serious damage. As far as we know, there has been not a single reported study of a vitrified mammalian brain, cooled to long term storage temperature and then rewarmed. There have been reports of encouraging progress; but the samples are very small, the evidence is indirect or partial, and there is a dearth of verification by independent investigators. Nevertheless, although its promise has been unfulfilled for many years, some serious people continue to believe that vitrification is the wave of the future.").

97 The act of freezing involves the solidification of a substance. WEBSTER's New World Dictionary 578 (College Edition 1968). Solidification means to become solid; to crystallize. Id. at 1388 .

98 Cryonics Myths, supra note 95 (emphasis omitted).

99 Wendy M Grossman, Patients Who are Frozen in Time, The Guardian, Feb. 14, 2008, (Technology), at 1, available at http://www.guardian.co.uk/technology/2008/ feb/14/research.cryonics.

100 Gregory M. Fahy \& Suja E. Ali, Cryopreservation of the Mammalian Kidney, 35 CRYOBIOLOGY 114 (1997).

101 Gregory M. Fahy et al., Cryopreservation of Organs by Vitrification: Perspectives and Recent Advances, 48 Cryobiology 157 (2004). 
genic preservation experiment using a domestic dog. ${ }^{102}$ The team lowered the body temperature of a dog to $20^{\circ}$ Celsius and replaced its blood with a specially formulated blood substitute. ${ }^{103}$ The animal's temperature was then lowered to $3^{\circ}$ Celsius. ${ }^{104}$ After 20 minutes, the dog was resuscitated, circulation was restored, and the dog's own blood was pumped back into its body. ${ }^{105}$ The animal was successfully thawed, and achieved full recovery. ${ }^{106}$ Admittedly, the dog was frozen for only 20 minutes and at a temperature much warmer than that used during the liquid nitrogen cooling of human bodies. ${ }^{107}$ Nonetheless, the experiment is clear indication of progress in the field of cryobiology. ${ }^{108}$

\section{c. Surgeries Performed During Suspended Animation}

In 1990, 24-year-old Donald Rogers suffered a life threatening aneurism which required immediate surgery. ${ }^{109}$ Due to the size of the swollen blood vessel and its likelihood to burst during the operation, physicians decided to completely stop the patient's circulation while the surgery was performed. ${ }^{110}$ Rogers was attached to a cardiac bypass machine that slowly cooled his body; his heart stopped beating at $72^{\circ}$ Fahrenheit. ${ }^{111}$ At $60^{\circ}$ circulation was stopped and his blood was removed. ${ }^{112}$ For 30 minutes, Mr. Rogers was clinically dead, that is, "an inanimate object, a patient in limbo, not measurably alive, but not quite dead either." 113 Once the aneurism had been repaired, his

102 Dog 'Spunky' After It's Frozen in Test, L.A. TIMEs, Mar. 31, 1987, at 3, available at http://articles.latimes.com/1987-03-31/news/mn-1527_1.

$103 \mathrm{Id}$.

$104 I d$.

$105 I d$.

$106 \mathrm{Id}$.

107 See supra note 70 and accompanying text.

108 Mike Darwin, president of Alcor, states that Alcor researchers have performed similar experiments on $15 \mathrm{dogs}$ as of September 1984. In these experiments, however, the dogs were suspended for 2 to 4 hours. Only 11 of the 15 dogs were revived successfully. T.W. McGarry, Revival of 'Frozen' Dog-Some Cold New Disclosures, L.A. Times, July 6, 1987, at 3, available at http://articles.latimes.com/1987-07-06/news/mn-1316_1.

109 Elisabeth Rosenthal, At Surgery's Frontier: Suspended Animation, N.Y. Times, Nov.

13, 1990, at C1, C12.

110 Id. at C12.

111 Id. at $\mathrm{C} 1$.

$112 I d$.

$113 I d$. 
blood was replaced and his body was "thawed." 114 At $70^{\circ}$, the heart began to twitch, and soon regained its rhythm. ${ }^{115}$ Because of the lowered body temperature, no brain damage occurred, and Mr. Rogers was later revived, or reanimated, and went on to live a normal, healthy life. ${ }^{116}$

Mr. Rogers was the tenth patient to have this surgery at Columbia Presbyterian Medical Center. ${ }^{117}$ The previous nine were alive and well at the time of his surgery, except for one in rehabilitation from a stroke during surgery. ${ }^{118}$ Suspended animation is beginning to lose its reputation as a notion of mere science fiction and is now used by surgeons to perform this delicate brain surgery. ${ }^{119}$

\section{d. Successful Revival After Three Hours of Clinical Death}

Ten years ago, the story of Anna Bågenholm shed new light on the effects of cold on brain tissue preservation. ${ }^{120}$ While skiing with some friends near Narvik, Norway, Anna lost her footing and slid down a steep, icy gully falling head first into a mostly frozen stream. ${ }^{121}$ Anna's head and upper body were stuck in the ice, submerged in the icy water below. ${ }^{122}$ Her friends attempted to free her, but the rapid current of icy water impeded their efforts. ${ }^{123}$ Eventually others arrived and, using a small shovel, they were able to release her from her icy trap. ${ }^{124}$ Anna's body was rigid, and she showed no signs of life. ${ }^{125}$ She had been submerged in the cold water for 80 minutes. ${ }^{126}$ Her body tempera-

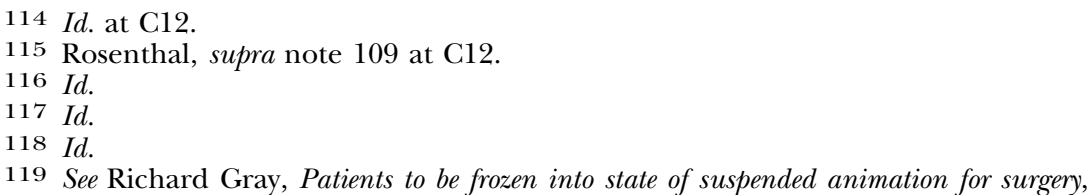
The Telegraph (Sept. 26, 2010, 9:45 AM), http://www.telegraph.co.uk/health/he althnews / 8024991/Patients-to-be-frozen-into-state-of-suspended-animation-for-surgery. html.

120 David S. Martin, From an Icy Slope, A Medical Miracle Emerges, CNNhealth.com, http:/ / www.cnn.com/2009/HEALTH/10/12/cheating.death.bagenholm/index.html (last updated Oct. 13, 2009, 10:29 AM); Skier Revived From Clinical Death, BBC News (Jan. 28, 2000, 1:50 PM), http://news.bbc.co.uk/2/hi/health/620609.stm.

121 Martin, supra note 120.

122 Id.; Skier Revived From Clinical Death, supra note 120.

123 Martin, supra note 120.

124 Id.

125 Skier Revived From Clinical Death, supra note 120.

126 Martin, supra note 120. 
ture had plummeted to $13.7^{\circ}$ Celsius, and she was flatlined. ${ }^{127}$ The emergency rescue team made the decision, "[w]e will not declare her dead until she is warm and dead."128 Anna was taken to a hospital where surgeons warmed her by rerouting her blood through a heart-lung machine. ${ }^{129}$ Approximately three hours after her heart had stopped beating, it began to contract. ${ }^{130}$ After about three hours of clinical death, Anna regained consciousness, and is alive today, with no signs of brain damage. ${ }^{131}$

Cryonicists believe stories like these are indicative of the awesome, life preserving power of the cold. As one cryonicist commented, while discussing the story of Anna Bågenholm, "[w]e used to not be able to bring people back to life at all. Then along came CPR. Now we bring people back to life who were clinically dead for 5 minutes. Here, with the intervention of cold, we see it happen after 3 hours. With further advancements in cryobiology, there is no reason why this same result can't occur after 3 years, or 300 years." ${ }^{32}$

\section{Advancements in Nanotechnology}

Throughout the first three decades following the public emergence of cryonics, the probability of successful reanimation was considered very slim. The main problem was that no one knew what sort of technology would be available to revive the cryogenically frozen dead, or when. ${ }^{133}$ The hope behind cryonics is based on faith that medical and biological sciences would continue to develop, and that the necessary technology to successfully thaw and repair a preserved human being would be discovered and perfected. ${ }^{134}$ Yet, even the creativity of modern science fiction authors failed to provide concise predictions of what this technology will be.

127 Id.

128 Id.

$129 I d$.

130 Id.; Skier Revived From Clinical Death, supra note 120.

131 Skier Revived from Clinical Death, supra note 120 ("Eight months on, Anna says the only lasting effect is a tingling in her hands."); see also Martin, supra note 120.

132 Telephone Interview with Brian O'Neill, supra note 76.

133 Jerry Emanuelson, Nanotechnology, Futurescience, LLC, http:/ /www.futuresci ence.com/nanocryo.html (last visited Nov. 28, 2010).

134 Id.; see also ETTINGER, supra note 22, at 1. 
With recent developments in the field of nanotechnology, this blind faith in future science has transformed into a viable, foreseeable prospect for resolving this unanswered concern. Nanotechnology is the study of "systems for transforming matter, energy, and information that are based on nanometer-scale components with precisely defined molecular features."135 $\mathrm{Na}-$ notechnology, experts say, has the potential to produce unique materials and devices with a vast range of applications, including medicine. ${ }^{136}$ As applied to cryonics, the theory is that these devices can be deployed into the human body to repair the damage caused during long term cryonic suspension, as well as cure the underlying ailment which caused the patient's death. ${ }^{137}$ As Robert Ettinger put it, "[p] eople are made of atoms and molecules. To restore youth and health, all you have to do is make wrong molecules into right molecules, and get them in the right places." 138

\section{Obstacles to Overcome}

Though no longer viewed as pure science fiction by many credible scientists, the theory of cryonic suspension of a human being faces many challenges before acceptance as a legitimate science. Vitrification, as discussed above, has been a remarkable development in the field of cryonics. Yet along with its benefits, vitrification has its drawbacks. ${ }^{139}$ A prime concern is that the cry-

135 McGraw-Hill Dictionary of Scientific and Technical Terms 1398 (6th ed. 2003)

136 See Mihail C. Roco, Nanotechnology's Future, ScI. Am., Aug. 2006, at 39; see also K. Eric Drexler, Engines of Creation: The Coming Era of Nanotechnology (Anchor Books 1986).

137 John Paul LaBouff, "He Wants to Do What?" Cryonics: Issues in Questionable Medicine and Self-Determination, 8 Santa Clara Computer \& High Tech. L.J. 469, 495 (1992) ("[Nanotechnology] has been a goal of cryonicists for many years. It is one of the keys to reanimation, since such technology would not only serve as a way to reverse the injurious effects of long term freezing, but could cure the underlying cause of death."); Sonia Arrison, A Conversation About Cryonics, TechNewsWorld (Oct. 27, 2007, 4:00 AM) http://www.technewsworld.com/story/59748.html?wlc=1257208033\&cwlc=12 57304232 \&wlc=1290401644 ("The theory is that as computing power grows and nanomedicine advances, tiny robotic arms smaller than mitochondrion will be able to enter a cryopreserved body and repair cell damage."); see also Cryonics, RALPH C. MERKLE, http:/ / www.merkle.com/cryo (last visited Nov. 21, 2010) ("A future medical technology based on mature nanotechnology should be able to preserve and restore health in all but the most extreme circumstances.").

138 Robert Ettinger, Nanotechnology and Cryonics: An Introduction, CRYOnics InstiTUTE, http://www.cryonics.org/nanointro.html (last visited Nov. 21, 2010).

139 Robert Ettinger himself identifies several limitations of vitrification including 
oprotectants used to replace the human blood are toxic. ${ }^{140}$ Thus, the use of cryoprotectants in the vitrification process merely trades one harm for another. In order to achieve the "best preservation," scientists must develop a procedure that not only prevents the formation of ice crystals while cooling, but "eliminate[s] the toxicity from cryoprotectants."141

An additional concern that must be overcome is that vitrified human flesh has a propensity to fracture at cold temperatures. ${ }^{142}$ For the cryonicists' dreams to come to fruition, there must be either technology available at the time of preservation that will prevent fracturing or, alternatively, technology available in the future that will repair the fractures. Tanya Jones, Alcor's Director of Technical Operations, states that the cause of the fractures is not clear, ${ }^{143}$ but they are "working on the engineering . . . to eliminate this problem." 144

Another issue limiting the probability of successful cryonic preservation is the inherent delay in achieving preservation. At present, it is not legal to vitrify a live human being, ${ }^{145}$ so the preservation team must wait until the patient is pronounced clinically dead before vitrification process begins. Ideally, the body

the difficulty in maintaining the proper temperature, the need for very fast cooling and warming, and the toxicity of the cryoprotectants used in the vitrification process. Ettinger, supra note 96.

140 Aschwin de Wolf, Cryoenzymology and Cryoprotectant Toxicity, Depressed MetaboLISM (Sept. 4, 2008), http://www.depressedmetabolism.com/2008/09/04/cryoenzym ology-and-cryoprotectant-toxicity ("The major limiting obstacle to reversible cryopreservation of complex organs is cryoprotectant toxicity. Elimination of ice formation through vitrification requires high concentrations of cryoprotective agents. These high concentrations of cryoprotectants can be toxic to tissues."); see also Grossman, supra note 99 (identifying cryoprotectant toxicity as a downside of the vitrification process).

141 Ben Best, Cryoprotectant Toxicity, Cryonics Institute, http://www.cryonics.org/ immortalist/march08/cryoprotectant.pdf (last visited Nov. 21, 2010).

142 Cryopreservation and Fracturing, Alcon, http://www.alcor.org/Library/html/ CryopreservationAndFracturing.html (last visited Nov. 21, 2010) ("One problem with cooling to temperatures well below the glass transition temperature is that mechanical stresses due to thermal contraction are no longer easily accommodated. Solids want to contract as they are cooled, but glassy solids cannot contract. If tissue is cooled to liquid nitrogen temperature, which is far below the glass transition temperature, these conflicting forces cause the tissue to fracture, or crack into pieces.").

143 Grossman, supra note 99.

144 Howard Witt, The Cold, Hard Facts on Cryonics, Chicago Tribune, Aug. 22, 2005, at 1, available at http://articles.chicagotribune.com/2005-08-22/news/0508220106_1_ alcor-life-extension-foundation-american-cryonics-society-preservation-process.

145 Vitrification of a life human would cause clinical death, and would be considered assisted suicide under the laws of most jurisdictions. See infra Part III.B. 
should be preserved at some point between clinical death and brain death. ${ }^{146}$ Clinical death is the "short interval after the heart has finally stopped, during which there is no circulation, no breathing, and no evidence of brain function, but when rescue is still possible." 147 Brain death, on the other hand, is the complete deprivation of oxygen to the brain, ${ }^{148}$ and is not reversible ${ }^{149}$. "Brain death follows clinical death almost immediately unless [preservation] procedures are started promptly, since the human brain under normal temperatures cannot survive loss of oxygen for more than six to ten minutes at most." 150 In a perfect scenario, a preservation team is on site and able to cool the brain and begin the vitrification process immediately upon a declaration of clinical death. ${ }^{151}$

In reality, this immediacy can only be achieved by patients suffering from illnesses where death is predictable within a narrow window of time. Typically, this pertains to the population of patients suffering from various terminal illnesses. For example, imagine the scenario involving a cryonics member diagnosed with lung cancer and given three months to live. The patient contacts a cryonics facility to be put on standby. As the months go by and death becomes imminent, a suspension team is placed on location at the hospital to begin immediate vitrification upon death, ensuring the patient is suspended before damage to the brain occurs. For lack of a better term, this represents the "ideal" scenario for the purpose of cryonic preservation.

The story is quite different, however, when the case involves a patient suffering from inoperable brain cancer. In cases involving either unexpected death or imminent death as discussed above, there exists at least some window between clinical death and brain death whereby the patient's brain can be preserved

146 See Arlene Sheskin, Cryonics: A Sociology of Death and Bereavement 14-15 (1979).

147 Sherwin B. Nuland, How We Die: Reflections on Life's Final Chapter 121 (1994)

148 SHESKIN, supra note 146 , at 15.

149 See Alicia Seibel, The Limits to Life: What the D.C. Circuit's Decision in Abigail v. Von Eschenbach Means for Medical Futility Statutes, 53 ST. Lours U. L.J. 1321, 1324 ("Brain death is considered the only situation where medical intervention of any sort is considered futile ....”).

150 Hirsh, supra note 52, at 378 .

151 See supra text accompanying notes 45-47, 50. 
with minimal damage. ${ }^{152}$ No such window exists for those dying of brain cancer - clinical death and brain death are simultaneous. ${ }^{153}$ If the cancer is allowed to consume the brain until death, there will be little, if any, brain function left to preserve. In order to prevent this inevitability, and ensure an opportunity for preservation while brain functions are still intact, it would be necessary for the patient to achieve clinical death by some other means before the cancer destroys the brain. Assisted suicide has been suggested, and rejected, as a means to achieve this result. ${ }^{154}$ Unfortunately for the cryonicist with brain cancer, the law in most states prohibits assisted suicide, even in cases where the patient's death is imminent. ${ }^{155}$

\section{Relevant Law}

\section{A. Laws Governing Cryonics}

At present, there is no legislation specifically addressing cryonic preservation. ${ }^{156}$ This is not to say, however, that there are no laws that apply to cryonics. A right to give all or any part of an individual's body has been found in the Uniform Anatomical Gift Act ("UAGA"). ${ }^{157}$ The UAGA, adopted in some form by all 50 states, ${ }^{158}$ allows for the donation of a human body or part only to an authorized donee as listed in Section 11 of the UAGA. ${ }^{159}$ An issue arises, however, over whether the UAGA was intended to include cryonics facilities in the list of specific donees found in Section 11. ${ }^{160}$

\footnotetext{
152 See supra text accompanying notes 147-50.

153 Brain cancer is "[a] mass of tissue cells possessed of potentially unlimited growth [in the brain] . . rob[bing] the host of nutrients necessary for survival, . . and unless recognized early and removed kills the host . . .." Webster's Third New International Dictionary (Philip Babcock Gove ed., 1993).

154 See, e.g., Donaldson v. Lungran, 4 Cal Rptr. 2d. 59 (Cal. Ct. App. 1992) (rejecting argument that brain tumor patient has right to state-assisted suicide prior to cryogenic suspension).

155 See infra Part III.B.

156 Adam A. Perlin, "To Die In Order To Live": The Need for Legislation Governing PostMortem Cryonic Suspension, 36 Sw. U. L. REv. 33, 37 (2007).

157 Unif. Anatomical GifT Act $\$ 4$ (2006).

158 Perlin, supra note 156 , at 38.

159 Unif. Anatomical Gift Act $\$ 11$ (2006).

160 The Uniform Anatomical Gift Act of 1968 included within its list of authorized donees "any bank or storage facility". Unif. Anatomical Gift Act \$3 (1968). A strong argument had been made for the contention that cryonics facilities were classified as a "storage facility", and should receive recognition as an authorized donee of human
} 
Three states have addressed the legality of cryonic storage: Arizona, California and Michigan. In 2004, Arizona State Representative Robert Stump put forward H.B. 2637 which was intended to regulate cryopreservation facilities under Arizona's Funeral and Embalmer's Board, removing such facilities from donee status under the UAGA ${ }^{161}$ Alcor, a cryonics facility located in Arizona, fought the proposed amendment, and the bill was later withdrawn. ${ }^{162}$ In Michigan, the Cryonics Institute is licensed as a cemetery through the Michigan Department of Energy, Labor and Economic Growth ("DELEG"). ${ }^{163}$ Following a 2003 agreement between the Institute and DELEG resolving a dispute over the Institute's right to operate, the facility was allowed to continue operations, but became subject to audits, inspections, and financial reporting. ${ }^{164}$ The agreement also required the Institute to set aside certain funds in an "Endowment Care Trust Fund" to cover maintenance expenses. ${ }^{165}$

In 1992, a California court addressed the issue of cryonics in the case of Alcor Life Extension Foundation v. Mitchell, where the court enjoined the State Department of Health Services

from prohibiting, instructing or directing against, or otherwise interfering with, the registration of deaths or the issu-

remains. In 1987, the Act was revised so that "storage facility" was removed, and "procurement organization [s]" was added to the list of authorized donees. UNIF. ANATOMICAL GIFT ACT $\$ 6$ (1987). The Act was again revised in 2006, with the list of permissible donees now including "organ procurement organization $[\mathrm{s}]$; or other appropriate person.” Unif. AnAtomical Gift Act $\$ 11$ (2006) (emphasis added).

161 H.B. 2637, 46th Leg., 2d Reg. Sess. (Ariz. 2004); Alcor Legislative Alert, AlcOR (Feb. 20, 2004), http://www.alcor.org/Library/html/legislation20040220.html (HB 2637 . . . proposes cryonics be regulated under the Funeral and Embalmer's Board and that Alcor's use of the Uniform Anatomical Gift Act (UAGA) be stripped.”).

162 Chronology of Attempted 2004 Cryonics Legislation in Arizona, Alcor, http://www. alcor.org/Library/html/legislation.html (last visited Nov. 23, 2010).

163 The agreement was made public by the Cryonics Institute. See Conditions to Licensure as a Cemetery, CRYONICS InSTITUTE, http://www.cryonics.org/immortalist/ march04/conditions.htm (last visited Nov. 23, 2010).

164 Cryonics Institute Now Licensed as Cemetery to Settle Dispute with State of Michigan, DeP't of Energy, Lab. \& Econ. Growth (Jan. 7, 2003), http://www.michigan.gov/ dleg/0,1607,7-154-10573_11472-84042-,00.html.

165 Conditions to Licensure as a Cemetery, supra note 164; see also Ben Best, News and Views: President's Report, Cryonics Institute (Jan. 2004), http://www.cryonics.org/ immortalist/january04/news.htm ("The terms of the licensure also require the creation of an Endowment Care Trust Fund ... . The interest from this fund can be used for patient maintenance and maintenance of CI's facility. The existence of a separate fund is required for all cemeteries, and is intended to provide an extra assurance that funds will be available to maintain our patients."). 
ance of disposition permits for the bodies of persons who have designated Alcor as a donee pursuant to the Uniform Anatomical Gift Act and who have directed that Alcor place their bodies in cryonic suspension. ${ }^{166}$

This ruling provided California residents with a right to cryonic preservation upon death. ${ }^{167}$ The subsequent question posed to California courts was whether a person had a similar right to preservation before death. The California court drew the line at post-mortem cryopreservation and refused to extend the right to include preservation methods that require the performance of assisted suicide. ${ }^{168}$ Like most states, California has strict laws prohibiting physician assisted suicide. ${ }^{169}$

\section{B. Right to Die and Assisted Suicide}

In 1990, in the case of Cruzan v. Director, Missouri Dept. Health, the United States Supreme Court resolved the issue of whether a citizen had a constitutional right to refuse medical treatment. ${ }^{170}$ The Court found that such a right did exist, and that it was grounded in the Due Process Clause of the Fourteenth Amendment. ${ }^{171}$ The Court noted, however, that only a competent person possessed such a right, since an incompetent "person is not able to make an informed and voluntary choice to exercise ... [the] right to refuse treatment or any other right." 172

In the Cruzan opinion, the Court went on to explain that the constitutional analysis does not end at the simple determination that a constitutional right exists. ${ }^{173}$ To determine whether a citizen's liberty has been violated, the courts must balance "his liberty interests [in refusing medical treatment] against the relevant state interests." ${ }^{774}$ The Court identified four state interests: "the preservation of life, the protection of the interests of inno-

166 Alcor Life Extension Found. v. Mitchell, 9 Cal. Rptr. 2d 572, 575 (Cal. Ct. App.

1992) (citations omitted) (quoting the trial court's order of injunction).

$167 \mathrm{Id}$.

168 Donaldson v. Lungran, 4 Cal Rptr. 2d. 59 (Cal. Ct. App. 1992).

169 Cal Penal Code $\$ 401$ (West 2010).

170497 U.S. 261 (1990).

171 Id. at 270, 278-79.

$172 I d$. at 280.

$173 \mathrm{Id}$. at 279 .

174 Id. at 279 (quoting Youngberg v. Romeo, 457 U.S. 307, 321 (1982)). 
cent third parties, the prevention of suicide, and the maintenance of the ethical integrity of the medical profession." ${ }^{175}$ Only if such legitimate state interests outweigh the patient's desire to end his life can the state constitutionally intervene. ${ }^{176}$ Since Cruzan, courts have been reluctant to find compelling state interests which outweigh the terminally-ill patient's desire to die with dignity. ${ }^{177}$ The same is not true, however, for patients asserting a right to assisted suicide, which arguably includes patients seeking post-mortem cryopreservation.

In 1997, in the twin cases of Washington v. Glucksberg ${ }^{178}$ and Vacco v. Quill, ${ }^{179}$ the Supreme Court held that there is no fundamental right to assisted suicide under the United States Constitution. ${ }^{180}$ State courts that have addressed the issue of assisted suicide have applied the Cruzan balancing test, weighing the interests of the individual against the interest of the state. ${ }^{181}$ Only in Montana did a court find that such a state constitutional right exists. ${ }^{182}$ Oregon and Washington established the right to assisted suicide through state statute. ${ }^{183}$ Other states addressing the issue have determined, either statutorily or through the courts, that the individual's desire for physician assisted suicide is outweighed by the state's compelling interests. ${ }^{184}$

175 Id. at 271.

176 Id. at 279.

177 E.g. In re Rosebush, 491 N.W.2d 633 (Mich. Ct. App.1992); In re Truselo, 846 A.2d 256 (Del. Fam. Ct. 2000).

178521 U.S. 702 (1997).

179521 U.S. 793 (1997).

180 Washington, 521 U.S. at 728; Vacco, 521 U.S. at 799-800.

181 E.g., Donaldson v. Lungran, 4 Cal Rptr. 2d. 59 (Cal. Ct. App. 1992); Krischer v. McIver, 697 So. 2d 97 (Fla. 1997); Baxter v. State, No. ADV-2007-787, 2008 WL 6627324

(Mont. Dist. Ct. Dec. 5, 2008), rev'd on other grounds, 224 P.3d 1211 (Mont. 2009).

182 See Baxter, 2008 WL 6627324.

183 See Oregon Death with Dignity Act, Or. Rev. Stat. \$\$ 127.800-.995 (2009); Washington Death with Dignity Act, WASH. REv. CoDE $\$ \$ 70.245 .010-.904$ (2010).

184 E.g., Alaska Stat. $\$ 11.41 .120$ (a) (2) (2009) ("A person commits the crime of manslaughter if the person intentionally aids another person to commit suicide."); CAL. Penal Code $\$ 401$ (West 2009) ("Every person who deliberately aids, or advises, or encourages another to commit suicide, is guilty of a felony."); HAw. REv. STAT. \$ 707-702 (1) (b) (2009) ("A person commits the offense of manslaughter if the person intentionally causes another person to commit suicide."); N.M. STAT. AnN. § 30-2-4 (2009) ("Whoever commits assisting suicide is guilty of a fourth degree felony."); S.D. CoDIFIED. LAWS $\$ 22-16-37$ (2009) ("Any person who intentionally in any manner advises, encourages, abets, or assists another person in taking or in attempting to take his or her own life is guilty of a Class 6 felony."). 
In Krischer v. McIver, the Florida Supreme Court utilized the Cruzan balancing test to determine that Florida's constitutional right to privacy did not encompass a right to commit suicide with the assistance of a physician. ${ }^{185}$ Under Florida's privacy provision, once a citizen asserts a violation of his right to privacy, the state must provide a compelling interest to justify the intrusion. ${ }^{186}$ The court acknowledged that it had performed similar balancing analyses in earlier right-to-die cases and found "in various contexts that there is a constitutional privacy right to refuse medical treatment." ${ }^{87}$ In those cases, the court "recognized the state's legitimate interest in (1) the preservation of life, (2) the protection of innocent third parties, (3) the prevention of suicide, and (4) the maintenance of the ethical integrity of the medical profession," and found that these interests "were not sufficiently compelling to override the patient's right of self-determination to forego life-sustaining medical treatment." 188 Conversely, the court found three of the four state interests in the Krischer case "so compelling as to clearly outweigh [the patient's] desire for assistance in committing suicide." 189 The court drew a distinction between a right-to-die case and an assisted suicide case, finding that the former involved a passive act, where the latter involved an affirmative act to end one's life. ${ }^{190}$

In a similar case, the Alaska Supreme Court recognized a fifth state interest: an "interest in protecting vulnerable persons." ${ }^{191}$ The court cites a report created by a New York task force stating, "if assisted suicide and euthanasia are legalized, the autonomy of some patients would be extended while the autonomy of others would be compromised by the pressures to exercise these new options." 192 Here, it seems the court placed at

185 Krischer, 697 So. 2d. at 103.

186 Id. at 102 (citing Winfield v. Division of Pari-Mutuel Wagering, 477 So. 2d 544 (Fla. 1985)).

$187 \mathrm{Id}$.

188 Id.

$189 \mathrm{Id}$. at 103.

$190 I d$. at 102-03. The court found "a sharp distinction . . . between disconnecting a respirator that would result in his death from "natural causes' . . . and an 'unnatural death by means of a "death producing agent." " Id. at 103 (quoting Satz v. Perlmutter, 362 So. 2d 160, 162 (Fla. App. 1978)). The Krischer court concluded that the state has an interest in preventing such an "affirmative destructive act." Id.

191 Sampson v. State, 31 P.3d 88, 96 (Alaska 2001).

192 Id. (quoting N.Y. State Task Force on Life and the Law, When Death Is 
least some weight on the fear that ill or aging seniors would feel pressured or obligated to end their lives prematurely rather than burden their families or society. The court also found the state had a compelling interest in maintaining the integrity of the medical profession, finding the state statute prohibiting assisted suicide "furthers the state's protective interests by promoting the integrity of the medical profession and fostering healthy physician-patient relationships." ${ }^{193}$ The Alaska Supreme Court ultimately refused to grant an exception to the state statute, concluding such social policy decisions should be left to the legislature. ${ }^{194}$

A different set of facts was presented in the case of Donaldson v. Lungren, where a California court of appeals addressed the issue of assisted suicide in the context of pre-mortem cryonics. ${ }^{195}$ Donaldson, diagnosed with a terminal brain tumor, sought "judicial declaration that he has a constitutional right to cryogenic suspension premortem with the assistance of others." ${ }^{196}$ The court acknowledged that " $[\mathrm{t}] \mathrm{o}$ determine whether Donaldson has suffered a violation of his constitutional rights, we must balance his interests against any relevant state interests." ${ }^{197}$ The court then listed the state's relevant interests in "preserving human life, preventing suicide, protecting innocent third parties such as children, and maintaining the ethical integrity of the medical profession." 198 The court, however, refused to balance these interests, and hastily concluded that Donaldson had no right to assisted suicide. ${ }^{199}$

The Court's conclusion was not a result of its stated balancing analysis. Rather, its determination was based on a blanket finding that the rights afforded terminally-ill patients choosing to refuse treatment are not similarly afforded to those requesting assistance in committing suicide. ${ }^{200}$ The court described life

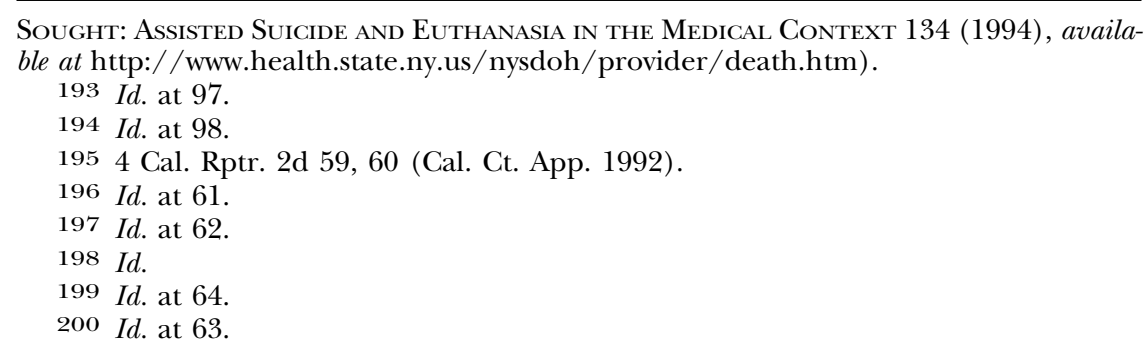


support as a "detour . . postpon[ing] an immediate encounter with death," thus, stopping treatment merely allows the inevitable to naturally occur. ${ }^{201}$ Conversely, the court viewed assisted suicide as an action which "hasten[ed] the encounter with death." ${ }^{202}$ On this distinction alone, the court ruled that Donaldson had no constitutional right to assisted suicide. ${ }^{203}$ This premature conclusion precluded the court from addressing Donaldson's compelling reasons to seek cryonic suspension before his natural death. The court failed to consider Mr. Donaldson's desire to be cryogenically preserved with the hopes of future reanimation. Assisted suicide for the purpose of absolute death, and assisted suicide for the purpose of seeking future medical treatment are vastly different, and the court should have focused on those differences. Although most states have determined that state interests outweigh the asserted right to assistance in committing suicide, balancing the particular interests involved in achieving pre-mortem cryopreservation would result in a different outcome.

\section{States' Interests are Not Compelling}

\section{Interest in Preserving Life and Preventing Suicide}

The Supreme Court has recognized that states have an undeniable interest in preserving human life and preventing suicide, and that states may rely upon these interests in restricting the right to self-determination of its citizens. ${ }^{204}$ In weighing these interests against a patient's right to pre-mortem cryopreservation, courts should recognize the distinction between suicide and cryonics. Suicide is the "action or act of intentionally killing oneself." 205 Thus, suicide requires the patient possess an intent to die. The theory behind cryonics, on the other hand, involves an ardent desire to live.

Courts have found that patients who voluntarily refuse life sustaining medical treatment are not committing suicide because they have no desire to die; they are merely choosing to

2014 Cal. Rptr. 2d at 63.

$202 I d$.

203 Id. at 63-64.

204 Cruzan v. Mo. Dep't of Health, 497 U.S. 261, 280 (1990).

205 The New Shorter Oxford English Dictionary, supra note 80, at 3135. 
hasten their death in the face of medical futility. ${ }^{206}$ This reasoning is equally compelling for patients choosing pre-mortem cryopreservation. In fact, if there is ever a situation when the intent to die is least present, it is during pre-mortem cryopreservation. No one chooses cryopreservation with the intent to die; in fact, cryonicists are often criticized for their overzealous intent to live. ${ }^{207}$ The question then arises: if future reanimation is possible, are those cryogenically preserved actually dead, or has their life merely been put on "pause?" Death is defined as the permanent cessation of life. ${ }^{208}$ Present science exists whereby cellular activities are preserved during cryopreservation and restored following a thawing process; thus cryopreservation is temporary, not permanent. ${ }^{209}$

The state's interest in preserving life and preventing suicide are weakened in cases involving a patient suffering from terminal illness. As the Supreme Court stated in Cruzan, the State's interest in preserving life is "greatest when an affliction was curable, 'as opposed to the State interest where, as here, the issue is not whether, but when, for how long, and at what cost to the individual [a] life may be briefly extended." 210 Further, some cryonicists argue that refusing technology available to save one's life is, in effect, a form of suicide. ${ }^{211}$

206 See, e.g., Superintendent of Belchertown State Sch. v. Saikewicz, 370 N.E.2d 417, 426 n.11 (Mass. 1977) (finding that refusing medical treatment is not necessarily suicide because "in refusing treatment the patient may not have the specific intent to die").

207 See Laura Wisniewski, For Some, Freezing Beats Alternative, The Free Lance Star, May 10, 1991. ("There's a kind of narcissism to being frozen and revived."); see also Kerry Howley, Until Cryonics Do Us Part, N.Y. Times (July 7, 2010), http://www.nytimes. com/2010/07/11/magazine/11cryonics-t.html.

208 The National Conference of Commissioners on Uniform State Laws in 1980 formulated the Uniform Determination of Death Act. It states that: "An individual who has sustained either (1) irreversible cessation of circulatory and respiratory functions, or (2) irreversible cessation of all functions of the entire brain, including the brain stem is dead. A determination of death must be made in accordance with accepted medical standards." Unif. Determination of Death Act $\$ 1$ (1980).

209 See supra notes 40-42, 100-101. The successful reanimation of cryogenically frozen cells and other tissues offers support for the contention that future science will provide the capability of reanimating entire human bodies. The argument is that the definition of death is relative, and that a cryonicist's belief in future reanimation should be considered in determining when his or her death actually occurs.

210 Cruzan v. Mo. Dep't of Health, 497 U.S. 261, 271 (1990) (quoting Superintendent of Belchertown State Sch. v. Saikewicz, 370 N.E.2d 417, 426 (Mass. 1977)).

211 Jerome Tuccille, Here Comes Immortality 17 (1973) ("It might be argued that to die a so-called 'natural death' is a form of suicide when one has the means of suspending biological life at his disposal? Is there any real difference between ending 
In the case of the terminally-ill brain cancer patient, not only are the state's interests diluted, the interests of the patient are amplified by his need to begin the cryopreservation process before his brain has become completely consumed by cancer. Given only months to live, and no present medical options to thwart death, the patient's only opportunity to retain some chance at future life is through pre-mortem cryopreservation. Further, where cryopreservation offers the only prospect of life, one could argue that the state's interest in preserving life does not compete with the patient's interest in cryopreservation; in fact, it supports that interest.

Even if it is found that pre-mortem cryopreservation offends the state's interests in preserving life and preventing suicide, the infrequency of use of this procedure to date indicates very little impact on the state's interests, yet presents a substantial deprivation of the interests of the rare individual denied this medical option. In the last decade, fewer than 120 humans have undergone cryogenic preservation upon death. ${ }^{212}$ And, although assisted suicide is legal in three states, no pre-mortem cryogenic preservations have been reported. ${ }^{213}$ Hence, the right would be asserted only by the exceptional cryonicist with terminal brain cancer or other degenerative brain disease. At some point in the

one's life abruptly with a bullet, or permitting oneself to go out through a process of gradual decay? Are not both a kind of self-destruction, the only real consideration being the time element?"); What is Cryonics?, CRYOnics Institute, http://www.cryonics. org/reprise.html (last visited Nov. 25, 2010) ("To refuse new life extension technologies could be a sin comparable to suicide."). But see George P. SMith II, Medical-Legal Aspects of Cryonics: Prospects for Immortality 29 (1983) ("In those cases where, after a determination of death is made, one seeks to have his or her remains cryonically preserved, the law should be less flexible than in the cases where suspension is undertaken before death.") (emphasis in original); Robert Ettinger, The Prospect of ImmorTALITY 11 (1964) ("Hence we need only arrange to have our bodies, after we die, stored in suitable freezers against the time when science may be able to help us.") (emphasis in original); Scientific Justification, supra note 51 ("Pronouncement of legal death is necessary before cryonics procedures can begin because cryonics is not yet a proven, recognized medical procedure.").

212 The Cryonics Institute has preserved 54 since January 2000. See Cryonics Institute (CI) Patient Details, Cryonics Institute, http://www.cryonics.org/patients.html (last visited Nov. 25, 2010). Alcor has preserved 60 since January 2000. See Complete List of Alcor Cryopreservations, Alcor, http://www.alcor.org/cases.html (last visited Nov. 25, 2010).

213 See Email from Ben Best, President, Cryonics Institute, to author (Nov. 21, 2009, 8:34 AM) (on file with author) ("I don't know of a CI patient that has committed suicide, although it may be hard to tell in some cases. CI strongly discourages suicide, but has no explicit policy against accepting a suicide victim.”); Email from Diane Cremeens, Membership Department Coordinator, Alcor, to author (Dec. 2, 2009, 4:48 PM) (on file with author) ("No patients were suicide or assisted suicide."). 
future, the utilization of pre-mortem preservation may increase commensurate to advancements in technology and biomedicine. As the prospect of successful reanimation increases, so too will the demand for cryonic preservation, including premortem preservation. When this point is reached, however, any offense to the state's interest in preserving life will have been reduced by the increased confidence in the procedure's capability of prolonging life. ${ }^{214}$ What is now considered experimental and controversial may become common practice in the future. ${ }^{215}$

\section{Interest in Maintaining Medical Ethical Standards}

There is no question that a patient's right to self-determination often conflicts with the ethical duties of physicians. ${ }^{216}$ Since Cruzan, however, courts are placing less emphasis on the importance of maintaining this "ethical integrity" in the context of a patient's right to die. Still, most jurisdictions addressing the issue uphold a distinction between the right to refuse medical treatment and a right to assisted suicide. ${ }^{217}$ The prevailing argument supporting this distinction is that the former is passive, and the latter is an affirmative act to hasten death. ${ }^{218}$ This distinc-

214 See cf. Atul Gawande, How Childbirth Went Industrial, The New Yorker, Oct. 9, 2006, at 59. The Cesarean section method for childbirth was illegal for much of history because of the likelihood that the procedure would result in the death of the mother. Now, with advancements in medicine, Cesarean sections are much safer and performed regularly. Id. If the Cesarean section was once a threat to the state's interest in preserving the mother's life, it has been alleviated by medical advancements. Similarly, with advancements in cryopreservation procedures, it too will become a safer alternative to "natural" methods, and any offenses to state interests will be diminished.

215 See Sidney H. Wanzer et al., The Physician's Responsibility Toward Hopelessly Ill Patients: A Second Look, 320 NEw ENG. J. MED. 844 (1989) (discussing that "practices that were controversial five years ago in the care of the dying patient have become accepted and routine.").

216 Assisted suicide involves the prescribing, or the administering of a lethal drug. The Hippocratic Oath requires physicians to "give no deadly medicine to anyone if asked, nor suggest any such counsel." TABer's Cylopedic Medical Dictionary 662 (Clayton L. Thomas ed., 14th ed. 1981).

217 Edward R. Grant \& Paul Benjamin Linton, Relief or Reproach?: Euthanasia Rights in the Wake of Measure 16, 74 OR. L. REv. 449, 462-63 (1995) (discussing how the majority of jurisdictions that recognize the right to refuse medical treatment disapprove of assisted suicide).

218 See supra note 190 and accompanying text. But see Cruzan v. Mo. Dep't of Health, 497 U.S. 261, 296 (1990) (Scalia, J., concurring) ("[T] he intelligent line does not fall between action and inaction but between those forms of inaction that consist of abstaining from 'ordinary' care and those that consist of abstaining from 'excessive' or 'heroic' measures."). 
tion becomes less relevant, however, in a situation involving assistance in achieving clinical death for the purpose of cryogenic preservation. In the case of a terminally-ill brain cancer patient seeking pre-mortem cryopreservation, if the physician acts passively, and allows the cancer to consume the patient's brain, absolute death will result. On the other hand, if the physician takes affirmative action to assist the patient in achieving clinical death before the cancer advances, the physician offers the patient a chance at future life. Thus, the active/passive distinction is a legal fiction, ${ }^{219}$ and should not be considered when determining whether a patient's right to privacy conflicts with state interests in maintaining medical ethical integrity. Instead, the patient's asserted right to privacy should be assessed on its merits, and balanced against the purpose of maintaining the physician's ethical integrity. The underlying goal of medicine is to preserve life. This goal runs in parallel with the theory of cryonics, not adversely to it.

Admittedly, the interest in maintaining medical ethical integrity may often outweigh a patient's desire to permanently end his or her life with the assistance of medical professionals. However, when determining whether medical integrity is at risk, legislators and courts should consider whether assisted suicide "in a particular case would significantly damage the reputation or ethical structure of the medical profession." ${ }^{20}$ Legislatures and courts have drawn a distinction between the right to refuse treatment and the right to assisted suicide. A similar distinction should be drawn between the right to assisted suicide involving a patient seeking permanent death, and the right to assisted suicide involving a terminally-ill patient seeking to extend his life.

\section{Interest in Protecting Vulnerable Persons and Preventing Abuse}

The state's interest in protecting vulnerable persons and preventing abuse stems mainly from the fear that the terminally ill would be pressured, guilted, or coerced into ending their life

219 Cf. Michael Ariens, Suicidal Rights, 20 Rutgers L.J. 79, 91 (1988) (arguing that the active/passive distinction is a legal fiction in the context of limiting the criminal consequences of for those who have assisted in a suicide).

220 Physician-Assisted Suicide and the Right to Die with Assistance, 105 Harv. L. Rev. 2021, 2035 (1992). 
prematurely in order to reduce their burden on the state or their families. ${ }^{221}$ Protecting the terminally ill from involuntary euthanasia is, of course, a legitimate state interest. ${ }^{222}$ But, this state interest is not implicated in the case of a sane, competent individual choosing immediate death in order to preserve a chance for future life through cryonic preservation. As Justice Stevens noted in his Vacco concurrence, the state interest in preventing abuse of the terminally ill does not apply if the patient requesting physician-assisted suicide was not a victim of abuse or suffering from depression and made a "rational and voluntary decision to seek assistance in dying." 223

If courts are now amenable to allowing unconscious, incompetent patients to refuse medical treatment based only on evidence of the patient's prior expressions, ${ }^{224}$ they should allow a fully-aware, competent individual to choose pre-mortem cryopreservation as a means of seeking future life.

\section{Are There Health Care Cost Savings to Consider?}

Another consideration, albeit quite morbid, is the amount of healthcare dollars potentially saved by allowing terminally-ill patients the right to pre-mortem cryopreservation. Healthcare expenditures surpassed the $\$ 2$ trillion mark in 2006, and are expected to continue to rise over the next decade. ${ }^{225}$ A disproportionate amount of these costs are incurred during the last year of a patient's life. In fact, Medicare spends a full 30 percent of its budget on beneficiaries in their final year of life. ${ }^{226}$ Even more disproportionately, data from Massachusetts and California show that about one third of expenditures in the last year of life are

221 E.g., Sampson v. State, 31 P.3d 88, 96 (Alaska 2001); Washington v. Glucksberg, 521 U.S. 702, 732 (1997). In Washington, the Supreme Court cautioned that "if physician-assisted suicide were permitted, many might resort to it to spare their families the substantial financial burden of end-of-life health-care costs." Washington, 521 U.S. at 732.

222 Katherine A. Chamberlain, Looking For A “Good Death": The Elderly Terminally Ill's Right To Die By Physician-Assisted Suicide, 17 Elder L.J. 61, 84 (2009) (discussing the state's interest in protecting elderly terminally ill patients).

223 Washington, 521 U.S. at 746.

224 Cruzan v. Mo. Dep't of Health, 497 U.S. 261 (1990).

225 National Health Expenditure Projections 2009-2010, Centers for Medicare \& MediCAID SERvices, tbl.1 (Sept. 2010), http://www.cms.gov/NationalHealthExpendData/ downloads/NHEProjections2009to2019.pdf.

226 Amber E. Barnato et al., Trends in Inpatient Treatment Intensity Among Medicare Beneficiaries at the End of Life, 39 Health Serv. Res. 363, 364 (2004). 
spent during the last month. ${ }^{227}$ A study done in 1998 concluded that the cost savings of legalizing assisted suicide in the U.S. would be somewhere between $\$ 336$ million and $\$ 4.67$ billion annually. ${ }^{228}$ Researchers admit that these numbers may be grossly underinflated due to several factors. ${ }^{229}$ First, these estimates are based on Medicare costs only, not costs for all dying patients. ${ }^{230}$ This is relevant because Medicare does not cover all health care costs, nor does it include nursing home costs. ${ }^{231}$ Further, these estimates do not include out-of-pocket expenses incurred by the dying patient. ${ }^{232}$ It is estimated that " $[\mathrm{n}]$ early one third of terminally ill patients with insurance used up most or all of their savings to cover uninsured medical expenses such as home care."233 Another factor not considered are the direct and indirect expenses incurred by family members caring for dying patients. ${ }^{234}$

Of course, even if thousands of terminally-ill Americans were to choose assisted suicide if it were made legal, very few

227 Ezekiel J. Emanuel et al., Managed Care, Hospice Use, Site of Death, and Medical Expenditures in the Last Year of Life, 162 Archives Internal Med. 1722, 1725 (2002).

228 Ezekiel J. Emanuel \& Margaret P. Battin, What are the Potential Costs Savings From Legalizing Physician-Assisted Suicide?, 339 New Eng. J. MEd. 167, 170 (1998). To calculate the number of U.S. cancer patients who might choose physician assisted suicide, the researchers extrapolated the rate of assisted suicide among cancer patients in the Netherlands, where physician assisted suicide is legal against the number of cancer patients in the United States. Id. at 168 . Approximately $2.7 \%$ of all deaths in the Netherlands came in the form of either euthanasia or physician assisted suicide. Id. Assuming a similar percentage of Americans would choose assisted suicide, if legal, approximately 62,000 assisted suicides would be performed. Id. This resulted in a savings of $\$ 336$ million. $I d$. at 170 . The researchers also performed calculations at a rate of $7 \%$, the percentage of dying patients who make inquires about or request euthanasia or physician-assisted suicide in the Netherlands. Id. at 169-70 tbls.1 \& 2. This resulted in an estimate of 161,000 American's choosing assisted suicide and $\$ 4.67$ billion in savings. $I d$. In the range of savings of $\$ 336$ million to $\$ 4.67$ billion, the most reasonable estimate is a savings of $\$ 627$ million. Id. at 171 .

$229 \mathrm{Id}$. at 169. The researchers also discussed that the estimated savings may be overinflated. Id. at 168-69.

$230 \mathrm{Id}$. at 169.

231 Id.

$232 I d$.

233 See How Much Do We Spend on End-of-Life Care?, Thirteen, http://www.thirteen. org/bid/sb-howmuch.html (last visited Nov. 27, 2010).

234 Kenneth E. Covinsky, et al., The Impact of Serious Illness on Patients' Families, 272 JAMA 1839 (1994). The study of 2661 seriously ill patients concluded that "[o]ne third (34\%) of patients required considerable care-giving assistance from a family member. In $20 \%$ of cases, a family member had to quit work or make another major life change to provide care for the patient. Loss of most or all of the family savings was reported by $31 \%$ of families . . . I Id. at 1839; see also Emanuel \& Battin, supra note 228, at 169, 17071 . 
would opt for pre-mortem cryonic preservation. ${ }^{235}$ Indeed, it is likely only a very small fraction of those choosing euthanasia or physician assisted suicide would go the route of pre-mortem cryonics. Further, if reanimation is possible, any end-of-life expenses saved now would likely be replaced by the future costs of revival, repair, and rehabilitation of the preserved patient, negating any financial benefit.

\section{Conclusion}

A brief look at the massive compilation of scientific, biological and medical advancements of the last two centuries demonstrates that human ingenuity is limitless. Given enough time, it seems anything is possible, even the prospect of immortality. The science of low-temperature preservation has already become mainstream - used today to preserve blood, organs, and even human embryos. Recent developments in cryobiology and nanotechnology have converted cryonicists' once-abstract faith in future science into a tangible, achievable aspiration. Although the technology required for successful human reanimation may still be many years away, the right to pre-mortem cryopreservation should be made available now, so that those future advancements may be reached.

The terminally-ill patient's interest in achieving cryonic preservation before ailments destroy all hope of reanimation is legitimate and substantial. When balancing the interests of the individual against the countervailing interests of the state, the court should consider the particular circumstances surrounding the patient's request for assistance in achieving clinical death. The right to pre-mortem cryopreservation should be distinguished from the right to assisted suicide. The terminally-ill cryonicist fervently seeks to extend his life - there is no suicidal

235 Oregon passed the Death with Dignity Act in 1997. After twelve years of legalized assisted suicide in the state, there is no record of any pre-mortem cryogenic preservation having been performed. But see Ben Best, Suicide E Cryonics, 41 IMmORTALIST 18 (2009), available at http://www.cryonics.org/immortalist/may09/Suicide.pdf. Ben tells a story of a young married couple planning to commit suicide following the completion of making arrangements to be cryogenically preserved through the Cryonics Institute. $I d$. The wife had been diagnosed with terminal ovarian cancer. Id. After a long discussion with Ben, the couple chose to forego the suicide plan. Id. 
intent. Thus, the state's interests in preserving life and preventing suicide are not offended.

Further, the ethical integrity of the medical profession will not be tarnished by allowing medical professionals to assist terminally-ill patients in protecting their only chance for survival, no matter how remote this chance may appear to be. The physician assisting in pre-mortem preservation should be treated no differently than the brain surgeon who clinically suspends the life of his patient in order to save his life. ${ }^{236}$ That doctor knows it is his patient's only chance of survival; the same is true for the terminally-ill brain cancer patient seeking pre-mortem cryopreservation. Additionally, the concerns of abuse and manipulation of the elderly that some courts have asserted when denying the right to assisted suicide are not present here. Rather, the patient is a competent individual, fully aware that his only option for future survival is immediate preservation.

For the above reasons, a patient suffering from a degenerative brain disease should be granted a constitutional right to assistance in achieving pre-mortem cryogenic preservation. Denying this right ensures either a prolonged, agonizing death with absolutely no hope of future life, or a cruder, unassisted form of suicide. No state interest is served by either of these outcomes. If the state's interest in preserving life is truly compelling, states should support patients who seek assistance in realizing their only conceivable chance of future life. 